\title{
Evaluation of actions of the official veterinary service to mitigate outbreaks of infectious laryngotracheitis and improve biosecurity on laying hen farms ${ }^{1}$
}

\author{
Izabella G. Hergot ${ }^{2}$, Christiane M.B.M. da Rocha ${ }^{3}$, Fabiana G. Xavier ${ }^{4}$, \\ Willian H.M. Santos ${ }^{5}$, Leticia B. de Oliveira ${ }^{5}$ (D) Nelson R.S. Martins ${ }^{6}$ \\ and Roselene $\mathrm{Ecco}^{7 *}$ (D)
}

\begin{abstract}
Hergot I.G., da Rocha M.B.M.C., Xavier F.G., Santos W.H.M., de Oliveira L.B., Martins N.R.S. \& Ecco R. 2021. Evaluation of actions of the official veterinary service to mitigate outbreaks of infectious laryngotracheitis and improve biosecurity on laying hen farms. Pesquisa Veterinária Brasileira 41:e06749, 2021. Setor de Patologia Animal, Departamento de Clínica e Cirurgia Veterinárias, Escola de Veterinária, Universidade Federal de Minas Gerais, Av. Antônio Carlos 6627, Belo Horizonte, MG 31270-901, Brazil. E-mail: ecco@vet.ufmg.br

Infectious laryngotracheitis (ILT), caused by an Alphaherpesvirus (Gallid herpesvirus-1; GaHV-1), has been noticed in the region of the Terras Altas da Mantiqueira, Minas Gerais. From 2010 to 2018, the "Serviço Veterinário Oficial" (SVO) of the "Instituto Mineiro Agropecuário" (IMA), implemented measures to prevent spread of the virus to other regions and control the disease in the area. Due to the close proximity and consequent epidemiological link among farms, the region was considered a unique epidemiological unit. To check the efficiency of the ILT control measures, we carried out: (1) a seroepidemiological survey, (2) questionnaires for evaluating biosecurity measures; and (3) an evaluation of the influence of farm population density on the occurrence of ILT. In 2016, 2017, and 2018, ILT was investigated using epidemiological and clinicopathological methods, along with GaHV-1 molecular detection. Serological survey was carried out on 24 farms in the quarantined region and on 13 farms from other regions of the state. In 2010 and 2018, questionnaires were applied to collect data and determine indicators of biosecurity practices in all farms of the quarantined area. The differences were then assessed (Wilcoxon's $p<0.05$ ). The results indicated positive serology throughout the region, although only on four farms $(16.6 \%)$ the chickens have clinical signs, macroscopic and histological lesions of ILT. The prevalence of viral infection increased from 2016 (27\%) to $2017(50 \%)$ and was higher in farms with a high stock density $(p=0.033)$. No disease, virus or antibodies were detected in the farms outside of the quarantined area. Although the biosecurity indicators had improved on all farms in the quarantined area $(p<0.05)$, the virus was active and circulating in the region. The contingency measures have contained the outbreak, but biosecurity practices are paramount in the control of new outbreaks. Official control will be maintained in the region, including surveillance of new cases and biosecurity procedures to mitigate the risk of the virus reaching other regions.
\end{abstract}

INDEX TERMS: Official Veterinary Service, outbreaks, laryngotracheitis, biosecurity, hen farms, Minas Gerais, Brazil, surveillance, ILT control, layer hen, epidemiology.

\footnotetext{
${ }^{1}$ Received on November 18, 2020.

Accepted for publication on December 11, 2020.

${ }^{2}$ State Agricultural Inspector/Veterinarian, Instituto Mineiro de Agropecuária (IMA), Rodovia Papa João Paulo II 4001, Cidade Administrativa Presidente Tancredo Neves, Belo Horizonte, MG 31630-901, Brazil. E-mail: izabella.hergot@ima.mg.gov.br

${ }^{3}$ Departamento de Medicina Veterinária, Universidade Federal de Lavras (UFLA), Campus Histórico, Av. Doutor Sylvio Menicucci 1001, Lavras, MG 37200-000,Brazil. E-mail: rochac@ufla.br

${ }^{4}$ Federal Agricultural Auditor/Veterinarian, Laboratório Federal de Defesa Agropecuária em Minas Gerais (Langro), Avenida Rômulo Joviano s/n, Pedro Leopoldo, MG 33600-000, Brazil. E-mail: fabiana.xavier@agricultura.gov.br
}

\footnotetext{
${ }^{5}$ Graduate Program in Animal Science with emphasis on Veterinary Pathology, Departamento de Clínica e Cirurgia, Escola de Veterinária, Universidade Federal de Minas Gerais (UFMG), Av. Antônio Carlos 6627, Belo Horizonte, MG 31270-901, Brazil. E-mail: willianhms@hotmail.com, leticiabatelli@gmail.com

${ }^{6}$ Departamento de Medicina Veterinária Preventiva, Escola de Veterinária, Universidade Federal de Minas Gerais (UFMG), Av. Antônio Carlos 6627, Belo Horizonte, MG 31270-901, Brazil. E-mail: nelrosmart@gmail.com

${ }^{7}$ Setor de Patologia Animal, Departamento de Clínica e Cirurgia Veterinárias, Escola de Veterinária, Universidade Federal de Minas Gerais (UFMG), Av. Antônio Carlos 6627, Belo Horizonte, MG 31270-901, Brazil. *Corresponding author: ecco@vet.ufmg.br
} 
RESUMO.- [Avaliação de ações do serviço veterinário oficial para bloqueio de foco de laringotraqueite infecciosa e melhoria da biosseguridade em granjas de postura.] Laringotraqueíte infecciosa (LTI), causada por um alfaherpesvírus (herpesvírus Gallid-1; GaHV-1), foi observada na região das Terras Altas da Mantiqueira, Minas Gerais. De 2010 a 2018, o Serviço Veterinário Oficial (SVO) do Instituto Mineiro Agropecuário (IMA) implementou medidas para impedir a disseminação do vírus para outras regiões do estado e controlar a doença na região interditada. Devido à proximidade e consequente vínculo epidemiológico entre as granjas, a região foi considerada uma unidade epidemiológica única. Para verificar a eficiência das medidas de controle de LTI, foram realizados: (1) pesquisa soroepidemiológica, (2) questionários para avaliar medidas de biosseguridade; e (3) avaliação da influência da densidade populacional da granja na ocorrência de LTI. Em 2016, 2017 e 2018, a LTI foi investigada usando métodos epidemiológicos e clínico-patológicos, com a detecção molecular de GaHV-1. O levantamento sorológico foi realizado em 24 granjas da região interditada e em 13 granjas de outras regiões do estado. Em 2010 e 2018, foram aplicados questionários para coletar dados e determinar indicadores de medidas de biosseguridade em todas as granjas da área interditada. As diferenças foram avaliadas $(p<0,05$ de Wilcoxon). Os resultados indicaram sorologia positiva em toda a região, embora apenas em quatro granjas $(16,6 \%)$ as galinhas apresentaram sinais clínicos, lesões macroscópicas e histológicas da LTI. A prevalência de infecção viral aumentou de 2016 (27\%) para 2017 (50\%) e foi maior em fazendas com alta densidade de alojamento $(p=0,033)$. Presença da doença, vírus ou anticorpos foram detectados nas granjas fora da área interditada. Embora os indicadores de biosseguridade tenham melhorado em todas as fazendas da área interditada $(p<0,05)$, o vírus está ativo e circulava na região. As medidas de contingência contiveram o surto, mas as práticas de biosseguridade são fundamentais para o controle de novos surtos. 0 controle oficial será mantido na região, incluindo a vigilância de novos casos e procedimentos de biosseguridade para mitigar o risco de transmissão do vírus para outras regiões.

TERMOS DE INDEXAÇÃO: Serviço Veterinário Oficial, laringotraqueite infecciosa, biosseguridade, granjas de postura, Minas Gerais, Brasil, fiscalização, LTI, controle, epidemiologia.

\section{INTRODUCTION}

Infectious laryngotracheitis (ILT) is an acute and contagious viral respiratory disease affecting layer and broiler chickens of all ages. The disease is caused by Gallid alphaherpesvirus-1 (GaHV-1), a member of the genus Iltovirus family Herpesviridae, subfamily Alphaherpesvirinae (ICTV 2011). In addition to mortality, ILT retards growth and reduces egg production (Guy et al. 2013). The disease mainly affects chickens, but it has also been found in pheasants, partridges, peacocks (Crawshaw \& Boycott 1982, Guy et al. 2013), and turkeys (Portz et al. 2008). Antibodies against GaHV-1 have been detected in ducks, but they are considered refractory to the virus (Yamada et al. 1980).

GaHV-1 establishes lifelong latency and infection in the trigeminal nerve ganglia of chickens (Bagust 1986, Williams et al. 1992). In experimental studies (Bagust 1986) and natural disease cases (Couto et al. 2015) of ILT, GaHV-1 was also detected in the tracheal mucosa in the absence of disease (Hughes et al. 1991, Couto et al. 2015). The latent virus can be reactivated and transmitted among birds in stressful situations (Hughes et al. 1989), such as prolonged transport, thermal fluctuations, inadequate handling, forced molting, housing of multiple age groups of chickens together, or intercurrent disease (Dufour-Zavala 2008).

Viral transmission mainly occurs through direct contact between birds (Johnson et al. 2004), although indirect transmission between farms is also important. Although GaHV-1 is sensitive to inactivation when isolated, it remains viable for long periods in carcasses, manure, equipment, and facilities if protected from sunlight and kept at low temperatures (Kingsbury \& Jungherr 1958, Ou et al. 2011).

Poor biosecurity, failure to clean and disinfect equipment and facilities, bacterial biofilms, and viral contamination of water lines are related to transmission within and between farms. Free-living birds, rodents, and domestic animals can mechanically carry the virus between farms. Proximity to backyard chickens also represents a risk for spreading GaHV-1 through fomites, as keepers of such animals generally do not carry out biosecurity practices such as cleaning, disinfecting facilities, and enforcing a fallow period (Dufour-Zavala 2008, Ou et al. 2011, Volkova et al. 2012, Pitesky et al. 2014). Access to farms by people (employees, veterinarians, and supplies sellers) is among the most common forms of transmission (Kingsbury \& Jungherr 1958, Dufour-Zavala 2008). However, another important source of contamination is manure, which maintains GaHV-1 stable for several days and can contaminate roads and properties close to highways during transport (Dufour-Zavala 2008, Chin et al. 2009).

The main forms of disease prevention involve effective biosecurity measures, maintaining an appropriate density of chickens on the farms, and ensuring the correct vaccination protocol (Dufour-Zavala 2008, Volkova et al. 2012). Live attenuated vaccines and viral-vectored recombinant vaccines are available to control ILT. In regions with mild or moderate viral challenge, vectored recombinant vaccines have been effective and provide a safer alternative than the continued use of live attenuated vaccines (Johnson et al. 2010), which can cause latent infections (Bagust 1986, Hughes et al. 1991, Guy et al. 2013) and reverse virulence after multiple passages from bird to bird, causing new outbreaks (Guy et al. 1991, García 2017). The emergence of new outbreaks is related to virus biology, including mutation and natural recombination, administration failures, low immunisation coverage, and poor biosecurity practices (OIE 2018, Guy et al. 1991).

The poultry-producing area of the Mantiqueira Highland region is the largest egg producer in Minas Gerais and covers the municipalities of Itamonte, Itanhandu, Pouso Alto, and Passa Quatro. In the database of the state "Serviço Veterinário Oficial" (SVO), 24 commercial layer-type farms are registered, with a total of 8,748.883 hens housed in facilities of the Californian style, modified Californian style, and 6-store vertical cages system sheds. The region represents the second largest producer and the largest exporter of eggs in Brazil.

Since the epidemic started in December 2010, the SVO has performed control actions. Due to the proximity and epidemiological links between farms, the region is considered a single epidemiological unit. Furthermore, the farms are 
close to backyard chickens and free-living wild birds, which favour viral circulation. As control measures, improvements in biosecurity practices were implemented on the farms, as well the use of viral-vectored recombinant vaccines against ILT and control of the movement of chickens, poultry product sellers, and manure.

In 2011, the "Ministério da Agricultura, Pecuária e Abastecimento" (MAPA) authorized, in Ordinance 14/2011, the use of recombinant vectored vaccines against ILT in the farms of the region, with a view to controlling the disease while avoiding the risks of ILT live vaccines, such as reversion of virulence and escape of an exotic viral strain to other regions. The strategy was the creation of routes that used specific roads to send the chickens to the processing plant while avoiding other poultry production regions. Furthermore, the transit of fresh manure between farms and composting areas began to be monitored.

The objectives of the present work were (1) to verify the effectiveness of the actions of the SVO and MAPA to prevent viral escape from the area and mitigate the disease, and (2) to evaluate whether the occurrence of the disease was related to higher density of chickens or failure in biosecurity practices. Clinical epidemiological surveys and laboratory tests were performed on farms from the quarantined region and farms outside this region. A questionnaire was conducted to assess biosecurity practices in the farms of the Mantiqueira Highlands region.

\section{MATERIALS AND METHODS}

From 2010 to 2018, an observational study was carried out on farms in the Mantiqueira Highland region, located in the municipalities of Itamonte, Itanhandu, Passa Quatro, and Pouso Alto, as well as on farms outside the region, considered at risk for ILT (Fig.1). During the study period, the quarantined area was subjected to continuous surveillance by the SVO, who collected samples and data to verify the actions taken to control the disease by those responsible for the farms.

The current project was approved by the Ethics Committee on the Use of Animals under protocol number 204/11 and 78/2014.

Sampling design. Epidemiological surveys and sampling were carried out in three stages. In the first and second stages, all farms in the quarantined area that housed chickens were sampled. The third stage was carried out on farms located outside the quarantined region considered at risk for ILT to verify the circulation of GaHV-1 outside this region. The first stage was carried out in November 2016

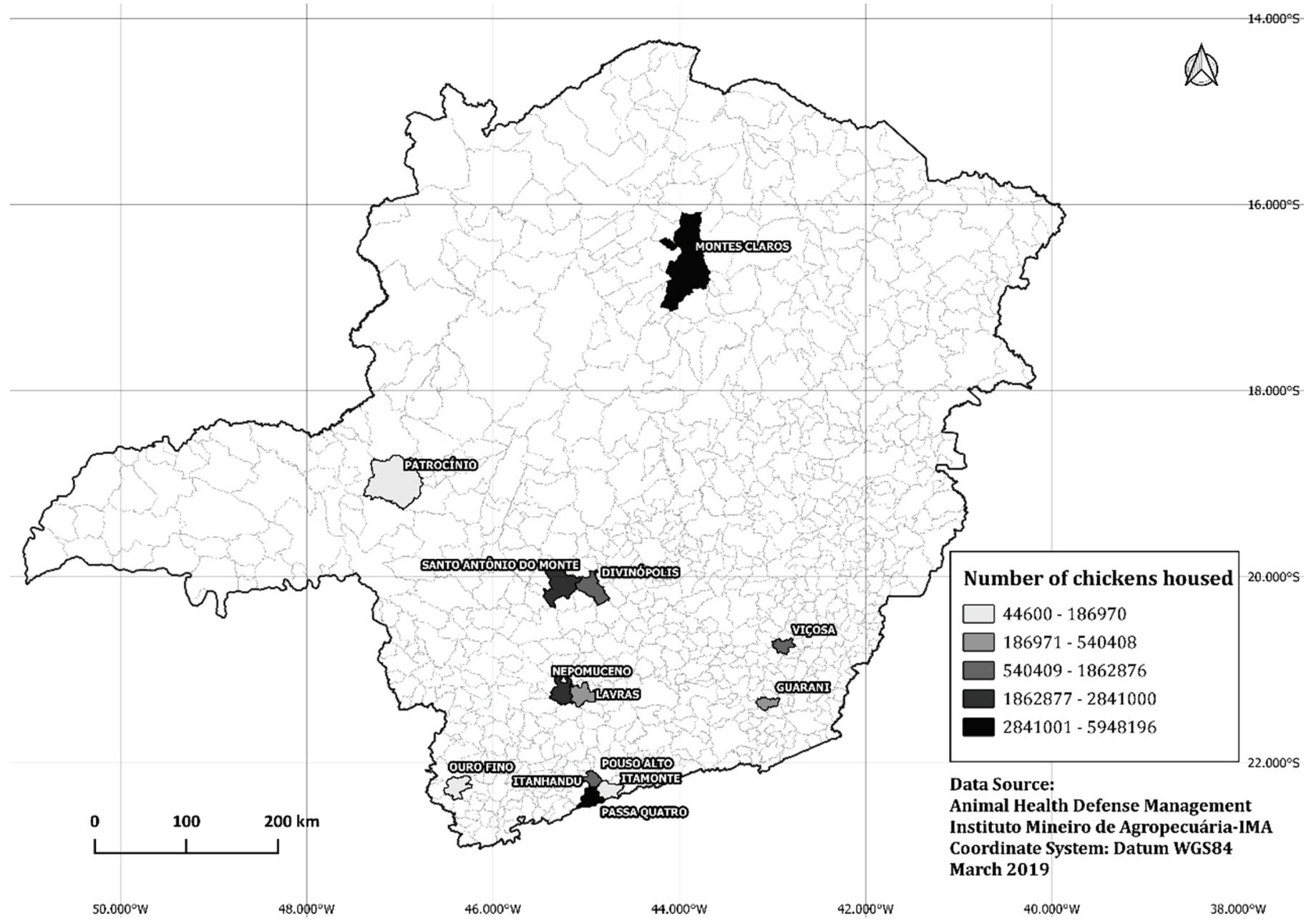

Fig.1. Location of seroepidemiological surveyed layer-type farms in different regions of state of Minas Gerais and with highest risk for ILT using the QGIS software. Municipalities and numbers of poultry farms are list as follows: Itamonte (2), Itanhandu (14), Pouso Alto (3), Passa Quatro (5), Lavras (1), Nepomuceno (1) Santo Antônio do Monte (4), Divinópolis (2), Patrocínio (1), Montes Claros (1), Guarani (1), Ouro Fino (1) and Viçosa (1). 
on 22 farms (17 egg-producing and five rearing farms). The second in October 2017 on 24 farms (18 egg-producing and six rearing farms). For identification, the farms were randomly numbered from 1 to 24, according to the sequence of collection. Two farms that were closed in 2016 were opened again in 2017, increasing the number of farms studied. At the end of the study, 21 farms in the region were still in production. The third stage was carried out in April 2018 on 13 farms located outside of the quarantined area across the state of Minas Gerais. The highest risk properties were chosen. The inclusion criteria for these farms were as follows: high density (over 50,000 chickens housed), a link between the farm and the chicken slaughterhouse, a low level of biosecurity (such as failure to isolate the houses, no control of entry and exit of people and vehicles, and no vehicle disinfection).

The sampling unit was the farm as houses are kept in close proximity on each farm and among farms, and ILT is a highly transmissible respiratory disease. Samples were collected from 10 chickens per farm, regardless of the number of chickens housed. In this regard, the sampling followed the pattern of official surveys carried out by the MAPA, which for ethical and economic reasons, seek to euthanize the minimal number of animals. As the objective was to determine the occurrence of GaHV-1 circulation and ILT, chickens from flocks with clinical signs of respiratory disease were preferably sampled. In the absence of clinical signs, the selection of the chicken on the farm was random.

Samples and collections for serological, molecular, and histopathological exams. Blood samples were collected from 220 chickens in 2016 and from 240 chickens in 2018. These were subjected to ELISA testing according to the manufacturer's instructions. Tracheal swabs for molecular examination were collected from 10 chickens, pooled in two pools of five swabs, and frozen at $-20^{\circ} \mathrm{C}$. Subsequently, the same chickens were euthanised by cervical dislocation and necropsied. The medial portion of the trachea and trigeminal ganglia (TG) were collected, stored in sterile microtubes, and frozen at $-20^{\circ} \mathrm{C}$. All chickens were examined for clinical signs before sample collection. A gross evaluation of lesions on the organs was performed during necropsy. The larynx, proximal and distal trachea, lungs, conjunctivae, and nasal concha (turbinates) were fixed in $10 \%$ neutral buffered formalin for 48 to 52 hours. The tissues were then cleaved and processed routinely for paraffin-embedded histopathology. Sections were cut $4 \mu \mathrm{m}$ thickness, stained with haematoxylin and eosin (HE), and examined under light microscopy. From each chicken, three or four histological slides were made. The tissues were examined by trained pathologists under conventional light microscopy to determine the presence or absence of typical ILT lesions (Hayashi et al. 1985, Fletcher \& Abdul-Aziz 2016).

For DNA extraction, each tracheal and TG sample was individually ground with a mortar and pestle using a commercial kit with reagents, according to the manufacturer's instructions. Detection of GaHV-1 DNA using quantitative real-time polymerase chain reaction (qPCR) was performed according to the method described by Callison et al. (2007).

The samples collected for histopathology were processed in the "Laboratório de Patologia Clínica" of the "Escola de Veterinária" of the "Universidade Federal de Minas Gerais" (UFMG) and "Laboratório Federal de Defesa Agropecuária” (LFDA), Pedro Leopoldo, Minas Gerais. The samples collected for serology and qPCR were processed at the LFDA in Campinas, São Paulo.

The laboratory results for ILT in chickens from these farms were categorised as follows: (1) negative - a. only serology was positive, b. respiratory clinical signs, but with negative histopathology and qPCR (diagnosis of other respiratory diseases was considered); (2) positive (disease present) - positive histopathology with pathognomonic lesions and the presence of clinical signs and macroscopic lesions;

(3) viral circulation - positive qPCR and negative histopathology.

Analysis of biosecurity on the farms affected by ILT. Biosecurity was analysed using a questionnaire applied by the SVO of Minas Gerais, with 2010 defined as the previous control period by the SVO (previous-CSVO) and 2018 as the post-control period by the SVO (post-CSVO). Scores from 0 to 3 were assigned to each criterion evaluated, as follows: 0 = absent, 1 = insufficient, 2 = minimum acceptable, and 3 = ideal.

Twenty-three factors were evaluated in the questionnaire and considered criteria for evaluation. The biosecurity indicator (BI) for each farm in the quarantined area was calculated by summing the scores of all items (Equation 1a), so it ranged from 0 to 69 points, with 0 points indicating a farm with no biosecurity practices and 69 indicating a farm with all the required biosecurity measures. The difference between the scores in 2010 (previous-CSVO) and 2018 (post-CSVO) was used to determine the Biosecurity Increment (BInc) of each farm (1b). The Wilcoxon test was performed to test whether each farm's BI was significantly different between the two periods.

(1) Calculated by farm:

$$
\begin{aligned}
& \text { a. } \mathrm{IB}_{\text {farm/year }}=\sum(\mathrm{Cr}) \\
& \text { b. } \mathrm{BInc}_{\text {farm }}=\mathrm{BI}_{2018-} \mathrm{BI}_{2010}
\end{aligned}
$$

Where Cr refers to the evaluation criteria.

The Shapiro-Wilk and Kolmogorov-Smirnov tests showed that the $\mathrm{BI}$ and BInc did not present normal distribution $(p<0.05)$. Thus, to analyse the BInc of each epidemiological unit, medians and quartiles were calculated. The median BI was defined as the general BI (GBI) (2a). The median BInc (2b) was defined as the general biosecurity increment (GBInc) of the quarantined area (2b). Spearman's bivariate correlation was tested among the $2010 \mathrm{BI}, 2018 \mathrm{BI}$, and BInc.

(2) Calculated by area:

$$
\begin{aligned}
& \text { a. GBI } \mathrm{(epidemiologic} \mathrm{unit/year)}=\text { Median BI } \\
& \text { b. GBInc } \\
& \text { (epidemiologic unit) } \\
& =\text { Median BInc quarantined area) } \\
& \text { (farms from quarantined area) }
\end{aligned}
$$

Each criterion addressed in the questionnaire was assessed separately based on the differences in the scores of all farms between 2010 and 2018 (3a). In this way, the questionnaire verified which parameters showed improvement (positive change, P), remained unchanged $(U)$, or regressed (negative change, N) (3b) within the study period.

(3) Calculated by criterion:

$$
\begin{aligned}
& \text { a. Difference of the criteria in the period-DCr }{ }_{(2010-18)}= \\
& \quad \mathrm{ScoreCr}_{2018}-\mathrm{Score}_{\mathrm{Cr}_{2010}} \\
& \text { b. Interpretation: } \\
& \text { c. If } \mathrm{DCr}{ }_{(2010-18)}=0 \text { (Unchanged); } \\
& \quad>1 \text { (positive/improvement in the biosecurity criterion); } \\
& \quad<1 \text { (Negative/worsening in the biosecurity criterion). }
\end{aligned}
$$

Statistical analyses were performed using SAS 9.4, R, and SPSS 20 softwares. For all hypothesis tests, a significance level of $5 \%$ was applied. The spatial distribution maps were made using QGIS geoprocessing software.

\section{RESULTS}

\section{Epidemiology}

ILT was considered exotic in Minas Gerais until December 2010, when it was diagnosed on farms in the Mantiqueira Highlands region. After the result was made official by the 
MAPA (DSA Technical Note No. 91, 17 December 2010), control measures such as quarantining the area, inspection of local farms, collection of samples, traffic analysis to investigate possible epidemiological (trucks transporting chickens to the processing plants), and inspection of permanent and mobile barriers for the movement of birds, eggs, and manure were adopted and remain to the present.

The total number of chickens housed in the region at the time of the first ILT notification (2010), was close to 8 million on 27 farms, representing a single epidemiological unit. However, at the end of the study (March 2019), even though the number of producing farms was reduced $(n=21), 8,748,883$ laying and rearing chickens were counted because the farms had expanded the accommodation capacity of their sheds.

\section{Results of serological, molecular and histopathological exams of chickens from quarantined farms}

In the quarantined area, all 24 farms had serologically positive chickens, regardless of whether they were vaccinated for ILT. The farms with chickens that were only positive by ELISA were considered negative.

Figure 2 shows the spatial distribution of farms in the ILT control region, according to the 2016 (Fig.2A) and 2017 (Fig.2B) surveys, detailed in Table 1, which shows the results of the histopathological and qPCR tests to determine whether ILT had occurred on the farms. Only four farms had chickens with histological lesions consistent with ILT (two in 2016 and two in 2017). The prevalence of histopathological positivity for ILT among the farms in 2016 was 9\% (2/22), while in 2017 it was 8\% (2/24). Regarding the prevalence of viral circulation, the number of farms with chickens that were positive for GaHV-1 increased from 2016 to 2017. In 2016, the occurrence of histopathological positivity for ILT on the farms was $27 \%(6 / 22)$, while in 2017 it was $45 \%(11 / 24)$ (Fig.3). However, the occurrence of the disease was limited to the three largest poultry producers (four farms) of the region, the same ones that presented cases at the time of the first notification (Table 2).
In the survey carried out in 2016, 16 farms were negative for both the disease and the circulation of GaHV-1. However, seven of them had chickens with respiratory signs and macroscopic lesions caused by other respiratory diseases. In the 2017 survey, the number of negative farms decreased to 15 , with nine farms showing chickens with clinical signs and respiratory lesions representing various respiratory diseases.

A significant difference $(p=0.033)$ in the median number of chickens housed was observed between ILT-positive (positive histopathology) and ILT-negative farms. The median number of chickens housed on farms negative for ILT was 69,886 (quartile $1=29,077$; quartile $3=195,859$ ), while the median number on farms positive for ILT was 814,393 (quartile $1=$ 317,969 ; quartile $3=1,300,734$ ). Furthermore, the median number of chickens housed on farms that were ILT negative by histopathology but positive for GaHV-1 DNA was larger than the median number on farms that were negative for both ILT and GaHV-1 DNA, with the difference tending towards significance ( $p=0.055)$. In other words, the number of chickens housed was related to the occurrence of clinical disease.

\section{Results of serological and molecular exams of chickens from farms outside of the quarantined area}

In the 13 commercial laying farms located outside the quarantined area, all chickens showed negative serology and qPCR. The farms had no history of ILT vaccination, and at the time of sampling, no respiratory clinical signs were observed in the chickens. In these municipalities, no events occurred and there was no history of changes in mortality.

\section{Biosecurity analysis of the farms in the quarantined area}

The adoption and implementation of biosecurity measures were monitored by the SVO in routine technical visits over 8 years (2010-2018) on all farms of the quarantined area. Regulatory instructions updated and published by MAPA in the last decade have enabled SVO to guide and inspect the adoption and implementation of appropriate biosecurity practices in layer-type farms in the region.

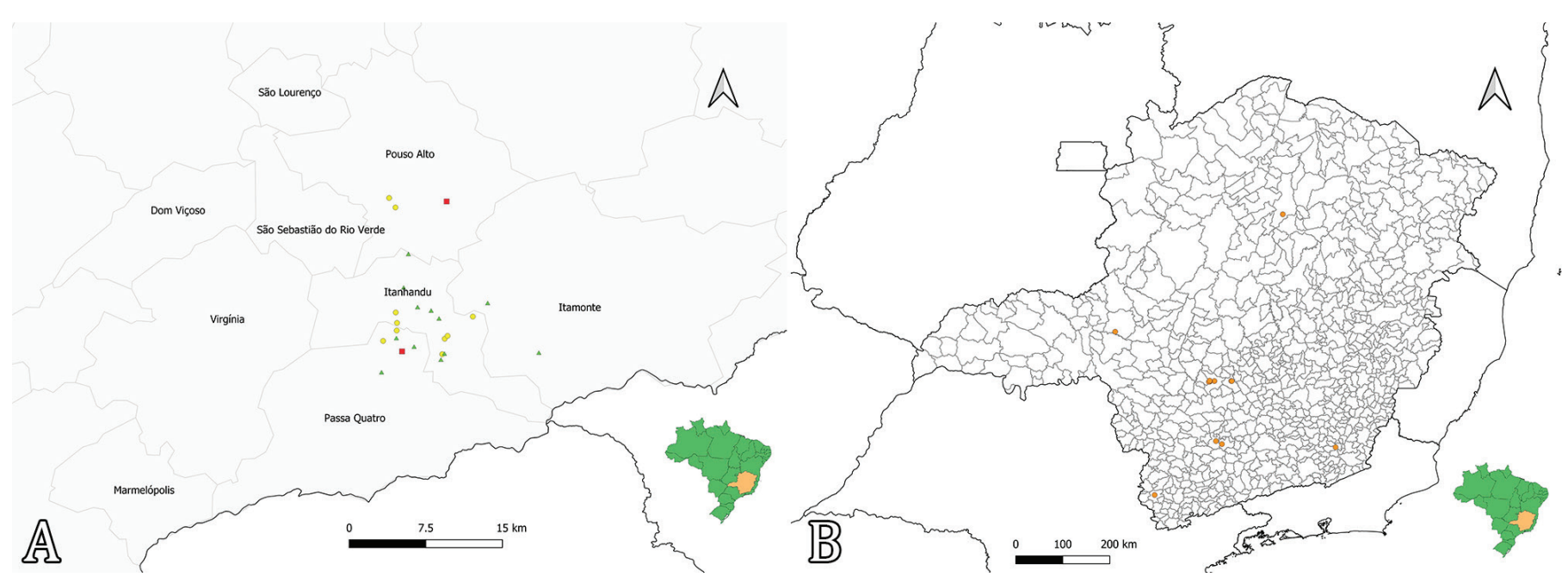

Fig.2. Farming distribution in the Mantiqueira Highlands Region, Minas Gerais, Brazil, according to the results of the survey for infectious laryngotracheitis (ILT) using QGIS software. (A) 2016, $\mathrm{n}=22$ farms and (B) 2017, $\mathrm{n}=24$ farms. Negative farms with positive serology (triangle), GaHV-1 circulation - positive qPCR, negative histology (ball), presence of ILT - positive PCR and positive histopathology (square). 
In the comparative assessment of the BInc in 2010 and 2018, all farms had improved biosecurity scores, with 18 (75\%) farms showing significant improvements, as determined by the Wilcoxon test $(p<0.05)$. Only on three farms $(12.5 \%)$ there were no improvements. These cases were not granted authorization for new poultry housing. Three farms (12.5\%) were closed in 2018 at the initiative of the owner and were not analyzed again in this study.

Thus, the GBI of the quarantined area varied from 27 in 2010 to 49 in 2018 (Table 3). Positive Spearman's correlations were observed $(p<0.001)$ between BI_2010 and BI_2018 $(\mathrm{r}=0.654)$ and between BI_2018 and BInc $(\mathrm{r}=0.696)$. These results demonstrated that the final result was correlated with the initial one, because the farms that had greater improvements in the last analysis were those that had better results in the first biosecurity analysis. With regards to the criteria scored in the biosecurity analysis, most criteria showed a positive statistical difference $(p<0.05)$ among the farms in the quarantined area. Some criteria showed unchanged scores throughout the study period ( $p>0.05)$. Only one criterion indicated worse biosecurity practices over the study period $(p<0.05)$ : number of flocks per shed, with an increase in population density.

The BI was used to evaluate the improvement in biosecurity practices on each farm (Table 3). Using this method, the proportion of farms with a good biosecurity score could be calculated. Thus, using the BI, the SVO (IMA) can analyse the mitigation of risk related to the biosecurity practices in an area. Table 4 demonstrates the changes in the number of farms with each score from 2010 to 2018. Most biosecurity criteria showed an improvement, based on the proportion

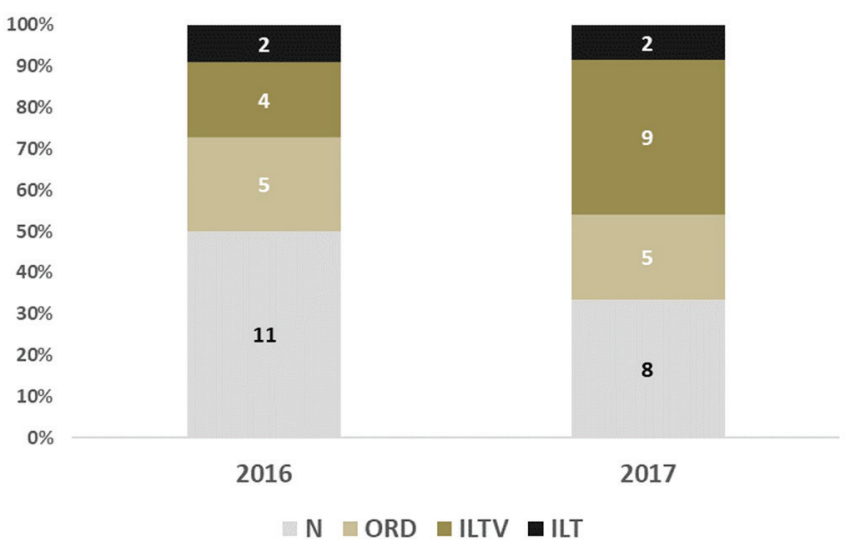

Fig.3. Frequency of infectious laryngotracheitis (ILT) diagnosed in 2016 and 2017 surveys in the Mantiqueira Highlands region. Other respiratory diseases (ORD). ILTV $=$ GaHV-1 circulation (8), $\mathrm{N}$ = farm negative for ILT (9).

Table 1. Farms and results according to clinical and laboratorial exams in chickens from Mantiqueira Highlands region, Minas Gerais, Brazil

\begin{tabular}{|c|c|c|c|c|c|c|c|c|c|c|c|}
\hline \multirow{2}{*}{$\mathrm{N}$} & \multirow{2}{*}{$\mathrm{ID}^{*}$} & \multicolumn{5}{|c|}{2016} & \multicolumn{5}{|c|}{2017} \\
\hline & & HTP & PCR & $\mathrm{CS}$ & RSL & Diagnosis** & HTP & PCR & $\mathrm{CS}$ & RSL & Diagnosis $^{* *}$ \\
\hline 1 & 11 & + & + & - & - & ILT & - & + & + & - & ILTV \\
\hline 2 & 7 & + & + & + & - & ILT & - & + & + & - & ILTV \\
\hline 3 & 20 & - & + & + & + & ILTV & + & + & + & + & ILT \\
\hline 4 & 22 & - & - & - & + & ORD & + & + & + & + & ILT \\
\hline 5 & 2 & - & + & - & - & ILTV & - & - & + & - & ORD \\
\hline 6 & 13 & - & + & - & - & ILTV & - & - & + & - & ORD \\
\hline 7 & 14 & - & + & + & + & ILTV & - & + & - & - & ILTV \\
\hline 8 & 3 & - & - & + & + & ORD & - & + & + & + & ILTV \\
\hline 9 & 18 & - & - & + & + & ORD & - & + & - & - & ILTV \\
\hline 10 & 21 & - & - & + & + & ORD & - & + & + & + & ILTV \\
\hline 11 & 19 & - & - & + & + & ORD & - & - & - & - & $\mathrm{N}$ \\
\hline 12 & 15 & - & - & - & - & $\mathrm{N}$ & - & + & - & - & ILTV \\
\hline 13 & 16 & - & - & - & - & $\mathrm{N}$ & - & + & - & - & ILTV \\
\hline 14 & 17 & - & - & - & - & $\mathrm{N}$ & - & + & + & - & ILTV \\
\hline 15 & 5 & - & - & - & - & $\mathrm{N}$ & - & - & + & + & ORD \\
\hline 16 & 10 & - & - & - & - & $\mathrm{N}$ & - & - & - & + & ORD \\
\hline 17 & 12 & - & - & - & - & $\mathrm{N}$ & - & - & - & + & ORD \\
\hline 18 & 1 & - & - & - & - & $\mathrm{N}$ & - & - & - & - & $\mathrm{N}$ \\
\hline 19 & 4 & - & - & - & - & $\mathrm{N}$ & - & - & - & - & $\mathrm{N}$ \\
\hline 20 & 6 & - & - & - & - & $\mathrm{N}$ & - & - & - & - & $\mathrm{N}$ \\
\hline 21 & 8 & - & - & - & - & $\mathrm{N}$ & - & - & - & - & $\mathrm{N}$ \\
\hline 22 & 9 & - & - & - & - & $\mathrm{N}$ & - & - & - & - & $\mathrm{N}$ \\
\hline 23 & 23 & - & - & - & - & no collection & - & - & - & - & $\mathrm{N}$ \\
\hline 24 & 24 & - & - & - & - & no collection & - & - & - & - & $\mathrm{N}$ \\
\hline
\end{tabular}

ID = Identification of the farm, HTP = histopathology (syncytial cells and intranuclear inclusion bodies), PCR = qPCR for GaHV-1, CS $=$ clinical signs of ILT, $\mathrm{RSL}=$ respiratory system lesion, ILT = positive diagnosis for ILT, ORD = other respiratory diseases, ILTV = circulation of GAHV- $1, \mathrm{~N}=$ negative farm; $(+)$ positive, (-) negative; * Sequences of identification of farms were organised according to sampling schedule, ${ }^{* *}$ all 24 farms were serologically positives for antibodies against GaHV-1. 
Table 2. Layer type-farms, geographic location, number of chickens housed and distance defined by the shortest distance from one farm to next farm

\begin{tabular}{|c|c|c|c|c|c|c|}
\hline FARMS & Farm ID & $\begin{array}{c}\text { Number of } \\
\text { houses }\end{array}$ & $\begin{array}{c}\text { Number of } \\
\text { chickens housed }\end{array}$ & $\begin{array}{l}\text { Shortest distance from } \\
\text { another farm (meters) }\end{array}$ & Results & Municipalities \\
\hline A poultry producer with multiple farms** & 21 & 34 & $3,394,738$ & 30 & ILTV & Itanhandu \\
\hline \multirow[t]{3}{*}{ A poultry producer with multiple farms** } & 18 & 12 & 396,605 & 2,000 & ILTV & Itanhandu \\
\hline & 19 & 7 & 330,947 & 593 & ORD & Itanhandu \\
\hline & 20 & 14 & $1,310,990$ & 3,700 & ILT & Pouso Alto \\
\hline \multirow{3}{*}{ A poultry producer with multiple farms** } & 9* & - & - & - & NEG & Itamonte \\
\hline & 10 & 9 & 51,084 & 700 & ORD & Itanhandu \\
\hline & 11 & 9 & 358,817 & 400 & ILT & Itanhandu \\
\hline \multirow[t]{2}{*}{ A poultry producer with multiple farms } & 4 & 6 & 69,886 & 6,500 & NEG & Passa Quatro \\
\hline & 13 & 17 & 261,906 & 1,440 & ILTV & Itanhandu \\
\hline A poultry producer with multiple farms & 2 & 8 & 166,057 & 593 & ILTV & Itanhandu \\
\hline A poultry producer with multiple farms & 17 & 5 & 28,748 & 30 & ILTV & Itanhandu \\
\hline \multirow[t]{2}{*}{ A poultry producer with multiple farms } & 15 & 5 & 128,296 & 1,000 & ILTV & Pouso Alto \\
\hline & 23 & 8 & 34,278 & 1,600 & NEG & Itanhandu \\
\hline A poultry producer with one farm & 1 & 9 & 104,249 & 1,440 & NEG & Itanhandu \\
\hline A poultry producer with one farm & 6 & 21 & 119,906 & 425 & NEG & Pouso Alto \\
\hline A poultry producer with one farm & 16 & 2 & 77,853 & 1000 & ILTV & Passa quatro \\
\hline A poultry producer with one farm & 24 & 4 & 23,875 & 3700 & NEG & Itanhandu \\
\hline
\end{tabular}

* Farms that were not housed on March of 2019, ${ }^{* *}$ poultry producers responsible for the largest farms on the region; ILTV = infectious laryngotracheitis virus, $\mathrm{ORD}=$ other respiratory diseases, NEG = negative; Data obtained on March of 2019.

Table 3. Biosecurity indicators of farms in the quarantined area from Mantiqueira Highlands region in 2010 and 2018

\begin{tabular}{|c|c|c|c|c|}
\hline \multirow{2}{*}{$\mathrm{N}$} & \multirow{2}{*}{ Identification of the farms* } & \multicolumn{2}{|c|}{ Biosecurity indicator (BI) } & \multirow{2}{*}{ Biosecurity increment $(\mathrm{BInc})^{* * \mathrm{~b}}$} \\
\hline & & $2010^{\mathrm{a}}$ & $2018^{\mathrm{a}, \mathrm{b}}$ & \\
\hline 1 & 5 & 24 & 51 & $27^{* *}$ \\
\hline 2 & 10 & 31 & 55 & $24^{* *}$ \\
\hline 3 & 20 & 27 & 51 & $24^{* *}$ \\
\hline 4 & 19 & 26 & 50 & $24^{* *}$ \\
\hline 5 & 11 & 31 & 54 & $23^{* *}$ \\
\hline 6 & 7 & 29 & 52 & $23^{* *}$ \\
\hline 7 & 22 & 27 & 50 & $23^{* *}$ \\
\hline 8 & 2 & 26 & 49 & $23^{* *}$ \\
\hline 9 & 1 & 25 & 48 & $23^{* *}$ \\
\hline 10 & 18 & 27 & 49 & $22^{* *}$ \\
\hline 11 & 16 & 26 & 48 & $22^{* *}$ \\
\hline 12 & 6 & 24 & 46 & $22^{* *}$ \\
\hline 13 & 15 & 27 & 48 & $21^{* *}$ \\
\hline 14 & 21 & 34 & 54 & $20^{* *}$ \\
\hline 15 & 3 & 28 & 47 & $19^{* *}$ \\
\hline 16 & 13 & 27 & 45 & $18^{* *}$ \\
\hline 17 & 23 & 27 & 44 & $17^{* *}$ \\
\hline 18 & 4 & 37 & 51 & $14^{* *}$ \\
\hline 19 & 24 & 21 & 33 & 12 \\
\hline 20 & 17 & 18 & 30 & 12 \\
\hline 21 & 12 & 26 & 37 & 11 \\
\hline \multirow[t]{3}{*}{ Geral } & Median & $27 \mathrm{~A}$ & 49B & $22 \mathrm{C}$ \\
\hline & Quartile 1 - Quartile 3 & $25.5-28.5$ & $45.5-51.0$ & $17.5-23.0$ \\
\hline & Mínimum - Maximum & 18-37 & $30-55$ & $11-27$ \\
\hline
\end{tabular}

$\mathrm{BI}=$ sum scores (0 to 3) of 23 criteria of biosecurity questioner applied by the OVS (minimum = 0, high = 69); General Biosecurity Indicator (GBI) = Median BI $\left({ }^{\mathrm{A}} \mathrm{GBI} 2010,{ }^{\mathrm{B}} \mathrm{GBI} 2018\right),{ }^{\mathrm{C}} \mathrm{BInc}(2010-2018) ;{ }^{*}$ Sequences of identification of farms were organised according to sampling schedule, ${ }^{* *}$ significant difference by the Wilcoxon test $(p<0.05)$. Three farms were closed before 2018 and were not counted in this year (ID 8, 9, 14). ${ }^{\mathrm{a}, \mathrm{b}}$ Spearman correlation $p<0.05$. 
of farms. Figure 4 shows a visual comparison from 2010 to 2018 in terms of the proportion of the farms classified with each score and criteria. For biosecurity criteria, grouped in Figure 4A (2010), the analysis revealed insufficient biosecurity, with a high predominance of scores of 0 (blue colour) and 1 (red). The same criteria in 2018 resulted in scores of 2 (green $=$ minimum acceptable) and 3 (purple $=$ ideal) - that is, satisfactory - demonstrating that most farms had improved significantly $(p<0.05)$ in most of the criteria $(13 / 23)$. For the biosecurity criteria grouped in Figure 4B, the proportion of the farms remained unchanged. "Number of flocks inside the shed" was the only criterion that showed no improvement: most farms had a score of 3 in 2010, which dropped to a score of 2 in 2018 (Table 4, Fig.4C). The criteria that remained unchanged were those that are almost impossible to modify, such as the distance among farms and the transport of manure to another area, which carries a high risk of spreading the virus. Other criteria in which good assessments predominated in 2010, such as control of pests and rodents, also remained unchanged. However, three criteria that needed to improve were the frequency of manure removal, the fallow period, and the daily report form of each flock in the farm (customised data). The short distance among several farms, as well as the proximity to highways and villages, can be seen on the geographic distribution map (Fig.5).

\section{DISCUSSION}

The surveillance carried out on the quarantined farms showed that the highest percentage of GaHV-1 infection in 2016 and 2017 occurred on farms with the highest density and with the highest movement of trucks, farmers, and non-farmer personnel. The occurrence of ILT was also confirmed on these farms. Other respiratory diseases were frequent in these farms, corroborating previous studies (Couto et al. 2016).

The farms that presented positivity by serology only were interpreted as negative, since it could not be determine whether the production of antibodies against GaHV-1 was induced by the vaccine or by the field virus. Even so, such farms remained quarantined, as they belong to the same epidemiological unit for ILT control.

Chickens from twelve farms of the quarantined region were positive for GaHV-1 infection by qPCR only in 20162017. Clinical signs and histologic lesions consistent with ILT were not found in these chickens, suggesting viral latency or persistence (Bagust 1986; Williams et al. 1992). This demonstrates a potential risk, as GaHV-1 can be reactivated by stressful situations that cause discomfort for chickens, including high-density poultry farms, climate change, and the occurrence of other diseases (Hughes et al. 1991, Dufour-Zavala 2008, Volkova et al. 2012). Thus, the region must be maintained as a permanent controlled area for ILT,

Table 4. Number of layer-type farms of Mantiqueira Highlands region in 2010 and 2018, according the scores used for biosecurity evaluation

\begin{tabular}{|c|c|c|c|c|c|c|c|c|c|c|c|}
\hline \multirow{3}{*}{$\begin{array}{l}\text { Classification } \\
\text { criteria }\end{array}$} & & \multirow{3}{*}{ Specific criteria } & \multicolumn{8}{|c|}{ Scores given in each evaluation } & \multirow{3}{*}{$\begin{array}{l}\text { Evaluation* } \\
2010-2018\end{array}$} \\
\hline & & & \multicolumn{4}{|c|}{2010} & \multicolumn{4}{|c|}{2018} & \\
\hline & & & 0 & 1 & 2 & 3 & 0 & 1 & 2 & 3 & \\
\hline \multirow[t]{6}{*}{ Sanitary control } & 1 & Cleaning and disinfection of sheds after unloading of chickens & 18 & 0 & 0 & 3 & 0 & 0 & 0 & 21 & $\mathrm{P}$ \\
\hline & 2 & Manure composting & 20 & 0 & 0 & 1 & 0 & 4 & 1 & 16 & $\mathrm{P}$ \\
\hline & 3 & Disposal of dead birds & 0 & 0 & 21 & 0 & 0 & 0 & 9 & 12 & $\mathrm{P}$ \\
\hline & 4 & Monitoring chickens for diseases & 21 & 0 & 0 & 0 & 0 & 0 & 0 & 21 & $P$ \\
\hline & 5 & Cleaning and disinfection of vehicles & 17 & 0 & 0 & 4 & 3 & 0 & 8 & 10 & $\mathrm{P}$ \\
\hline & 6 & Wearing clean clothes prior to entering in the houses & 6 & 15 & 0 & 0 & 4 & 12 & 3 & 2 & $\mathrm{P}$ \\
\hline \multirow{4}{*}{$\begin{array}{l}\text { Organization on } \\
\text { poultry operation }\end{array}$} & 7 & Information about the source of chickens in the form to the SVO & 21 & 0 & 0 & 0 & 0 & 11 & 2 & 8 & $\mathrm{P}$ \\
\hline & 8 & Register of flocks per house & 3 & 0 & 14 & 4 & 0 & 0 & 2 & 19 & $P$ \\
\hline & 9 & $\begin{array}{l}\text { Control of the movement of farmers and non-farmer personnel } \\
\text { from entering in the farms }\end{array}$ & 21 & 0 & 0 & 0 & 4 & 0 & 17 & 0 & $\mathrm{P}$ \\
\hline & 10 & $\begin{array}{l}\text { Control or prevention of the movement of unauthorized } \\
\text { vehicles entering in the farms }\end{array}$ & 20 & 0 & 0 & 1 & 3 & 13 & 0 & 5 & $\mathrm{P}$ \\
\hline \multirow[t]{2}{*}{ Facilities } & 11 & Perimeter fence to seclude the houses & 18 & 1 & 1 & 1 & 3 & 1 & 12 & 5 & $P$ \\
\hline & 12 & Wire on the sheds & 20 & 0 & 1 & 0 & 4 & 0 & 13 & 4 & $\mathrm{P}$ \\
\hline Productivity & 13 & Continuous egg production cycle** & 16 & 0 & 0 & 0 & 6 & 7 & 3 & 0 & $P$ \\
\hline \multirow[t]{5}{*}{ Sanitary control } & 14 & Vaccinal program & 0 & 0 & 0 & 21 & 0 & 0 & 0 & 21 & $\mathrm{U}$ \\
\hline & 15 & Fallow period between flocks & 18 & 1 & 2 & 0 & 19 & 0 & 2 & 0 & $\mathrm{U}$ \\
\hline & 16 & Frequency of manure removal & 2 & 2 & 16 & 1 & 2 & 2 & 12 & 5 & $\mathrm{U}$ \\
\hline & 17 & Control of rodents and insects & 0 & 0 & 0 & 21 & 0 & 0 & 0 & 21 & $\mathrm{U}$ \\
\hline & 18 & Cleaning the outside area & 1 & 0 & 0 & 20 & 1 & 0 & 0 & 20 & $\mathrm{U}$ \\
\hline \multirow[t]{2}{*}{$\begin{array}{l}\text { Organization on } \\
\text { poultry operation }\end{array}$} & 19 & $\begin{array}{l}\text { Licensed and accredited poultry veterinarian familiar with that } \\
\text { the type of operation }\end{array}$ & 2 & 0 & 14 & 5 & 2 & 0 & 10 & 9 & U \\
\hline & 20 & Daily report forms for each flock in the farm & 21 & 0 & 0 & 0 & 21 & 0 & 0 & 0 & $\mathrm{U}$ \\
\hline \multirow[t]{2}{*}{ Facilities } & 21 & Distance among farms & 2 & 2 & 6 & 11 & 2 & 2 & 6 & 11 & $\mathrm{U}$ \\
\hline & 22 & Distance from farms to roads & 1 & 0 & 1 & 19 & 1 & 0 & 1 & 19 & $\mathrm{U}$ \\
\hline Productivity & 23 & Number of flocks inside the shed & 0 & 2 & 0 & 19 & 0 & 2 & 8 & 11 & $\mathrm{~N}$ \\
\hline
\end{tabular}




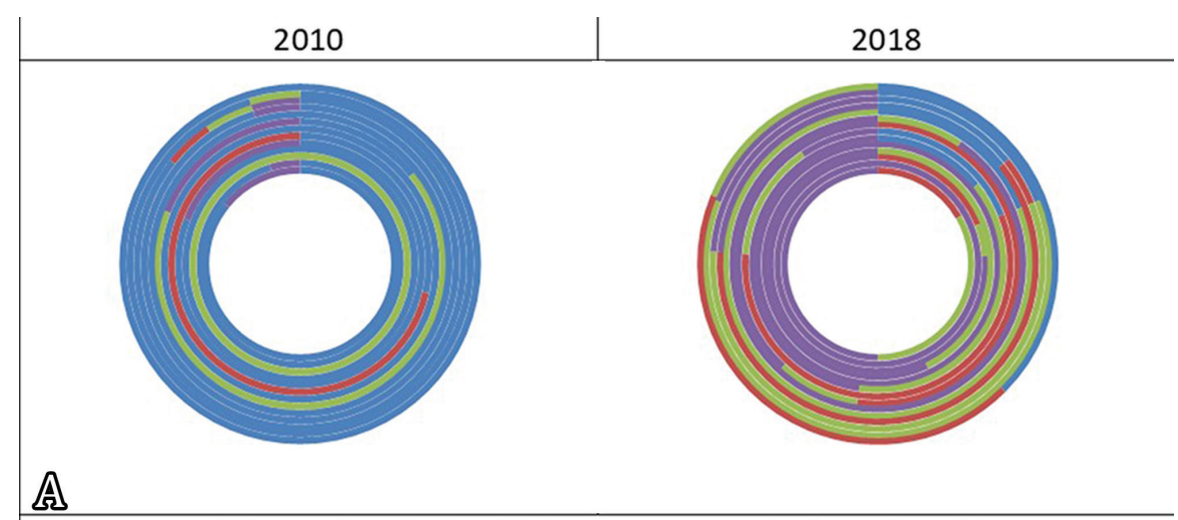

A

Scored biosecurity criteria with improvement on the farms * Positive $-\mathrm{P}$
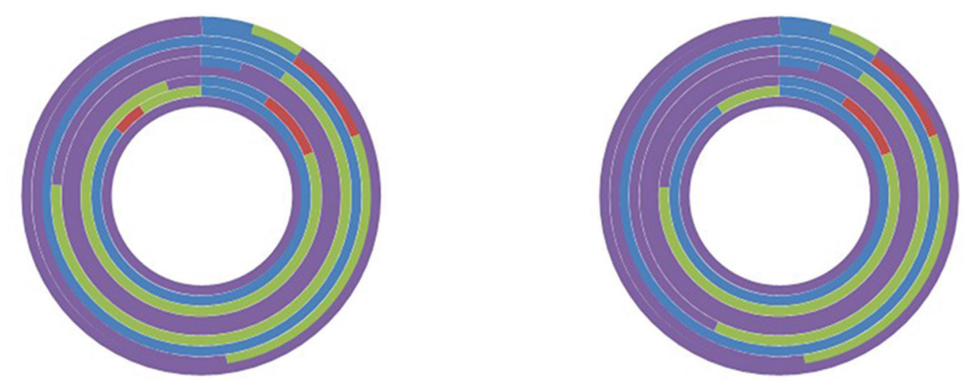

B

Scored biosecuriy criteria with no alterations on the farms* Unchanged - U

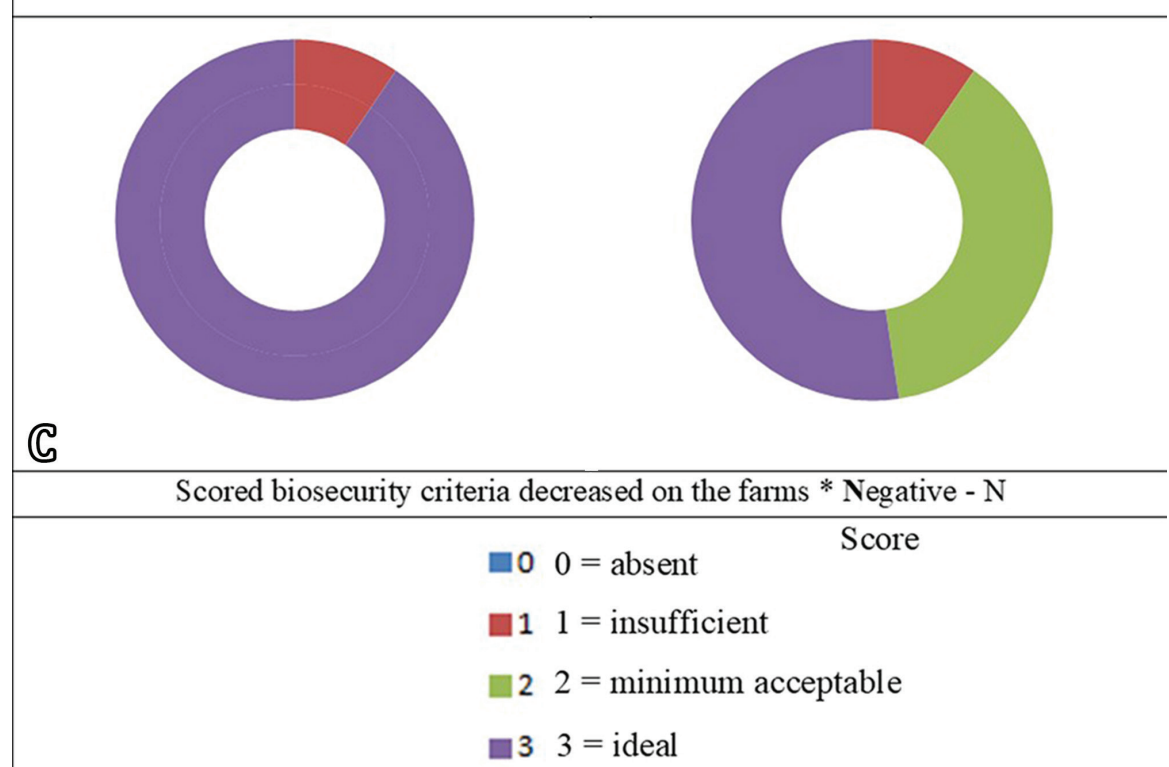

Fig.4. Comparative diagram of proportion of farms according to the distribution scores of each biosecurity criterion on farms in the quarantined area in 2010 and 2018. Score $0=$ absent, $1=$ insufficient, $2=$ minimum acceptable, $3=$ ideal. Each circle line represents the distribution of the scores according to each criterion in the biosecurity analysis, according to the following sequence from inside to outside of the circle. (A) Scored biosecurity criteria with improvement on the farms. Positive (P). 1. Cleaning and disinfection of sheds after unloading of chickens; 2. Manure composting; 3. Disposal of dead birds; 4. Monitoring chickens for diseases; 5 . Cleaning and disinfection of vehicles; 6 . Wearing clean clothes prior to entering in the houses; 7. Information about the source of chickens provided in the form to the OVS; 8. Register of flocks per house; 9. Control of the movement of farmers and non-farmers personnel from entering in the farms 10. Control or prevention of the movement of unauthorised vehicles entering the farms; 11 . Perimeter fence to seclude the houses; 12. Wire on the sheds; 13. Continuous egg production cycle ${ }^{*}$ ). (B) Scored biosecuriy criteria with no alterations on the farms. Unchanged (U) 14. Vaccinal program; 15. Fallow period between flocks; 16. Frequency of manure removal; 17. Control of rodents and insects; 18 . Cleaning the outside area; 19 . Licensed and accredited poultry veterinarian familiar with the type of operation; 20 . Daily report forms for each flock in the farm; 21. Distance among farms; 22. Distance among farms and roads. (C) Scored biosecurity criteria decreased on the farms. Negative $(\mathrm{N})$. 23. Number of flocks and sheds. 
regardless of whether the clinical disease occurs. The results of the present study demonstrated that ILT outbreaks were clustered in the highest-density farms because these farms tended to increase housing per shed to reach the highest productivity. Population increases on farms is one factor that strongly affects mitigation measures.

With regards to biosecurity practices on the farms in the quarantined region, there was improvement between the first ILT outbreak and the last survey. However, the implementation of these practices is still limited on some farms, and some procedures must be improved, such as the frequency of manure removal, control of vehicle (including trucks transporting chickens) and personal transit onto farms, and cleaning and disinfection of the external area of the sheds. Several studies have demonstrated the importance of indirect transmission of GaHV-1 via fomites to susceptible chickens. Indirect sources include vehicles, viruses suspended in dust, transmission via clothes and boots that harbour the virus, other infected birds (such as backyard chickens), or even other animals such as dogs (Kingsbury \& Jungherr 1958, Johnson et al. 2004). Roads can be a source of virus transmission because trucks transporting infected birds to chicken processing plants can spread viruses to other farms and regions (Pitesky et al. 2014).
The greatest challenge in the region is the proximity of the farms: some are less than 100 meters from each other. Thus, the SVO has stated that these farms are a single epidemiological unit because it is difficult of seclude them. Another risk factor for the spread of GaHV-1 are ventilating houses, which can release feathers to the external environment (Volkova et al. 2012). This was the specific case of one farm with positive results for ILT in the present study, which was located 30 and 1000 meters from two other farms, respectively. Thus, the number of farms with viral circulation increased from six in 2016 to 12 in 2017, demonstrating how difficult it is to control the virus, as GaHV-1 is directly and indirectly transmissible.

Evidence obtained from genomic sequencing of live ILT vaccines and field strains has indicated that natural recombination between the vaccine and field viruses may result in the emergence of new virulent strains of GaHV-1 (Coppo 2013). Based on these studies, farms must adopt and maintain strict biosecurity measures to prevent the spread of viruses to other regions. Increasing the distance among farms is not possible, except by depopulating and removing the houses to another area, which is not currently feasible. Therefore, it is recommended to install fences, which effectively prevent people and other domestic animals from entering the poultry operation without control. In the region, many small properties have backyard chickens, which reinforces

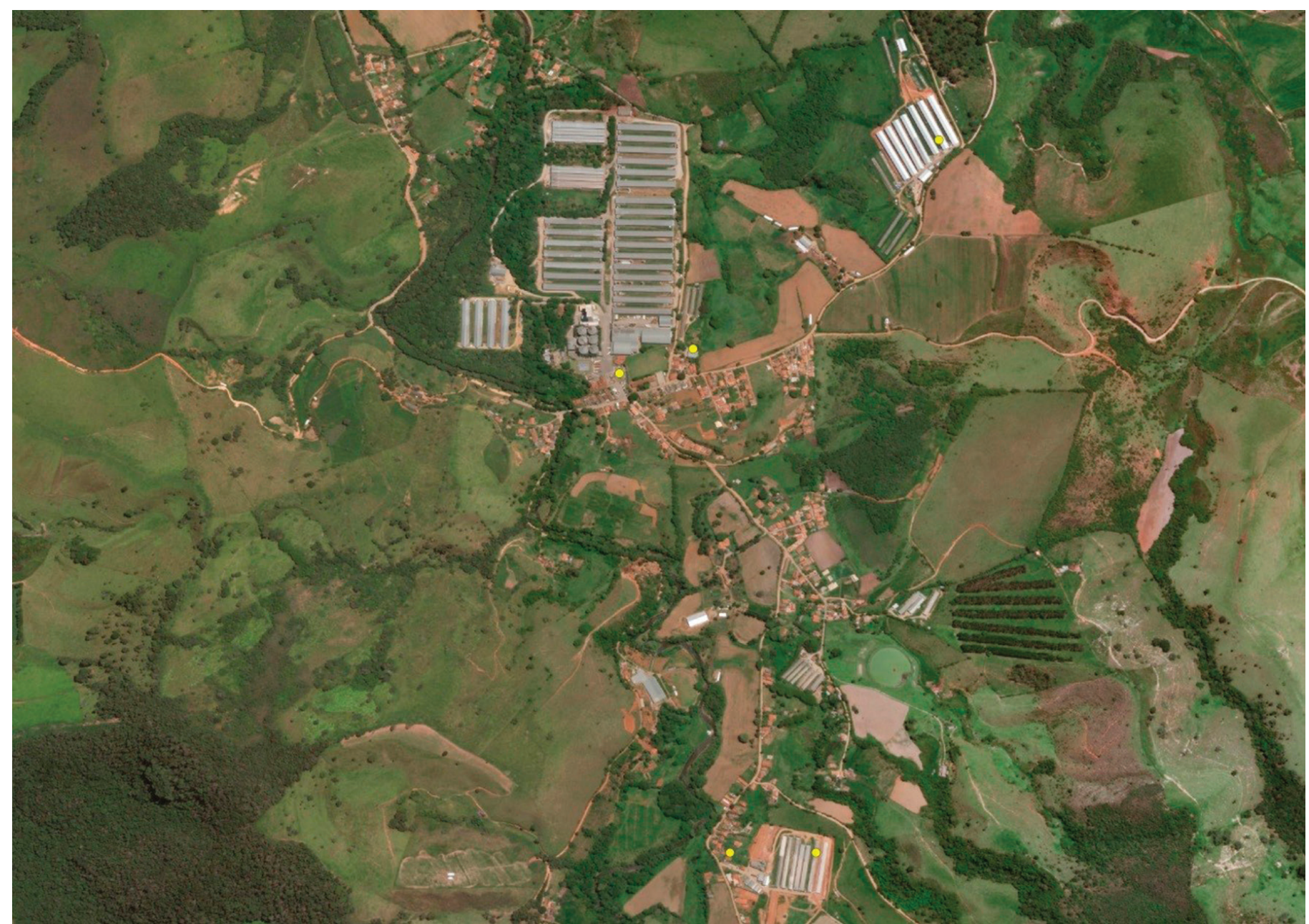

Fig.5. Satellite image of some farms in close vicinity to a village and roads in the Mantiqueira Highlands region. Created using QGIS software. 
the importance of fences. Vegetation could also improve the barrier surrounding the farms. Among other sources of risk, in addition to the proximity of the farms, are highways and vicinal roads, which allow free access to the farms.

Rapid diagnosis and vaccination of chickens, which are associated with effective biosecurity procedures and cooperation between the poultry industry and the SVO are essential for controlling of ILT. Previous studies on ILT control have reported that satisfactory results were only obtained after adopting strict biosecurity practices, including a fallow period after cleaning and disinfecting the sheds between flocks (Ou et al. 2011). The Office International des Epizooties (OIE) advises that farmers implement a minimum fallow period of 14 days. The lack of a fallow period between flocks on farms in the quarantined region was one major problem identified in the biosecurity analysis in the present study, and it did not improve over the years. This demonstrates that effective inspection and improvements in biosecurity practices in the region are fundamental for controlling the disease.

Cleaning and disinfection of sheds and water drinkers are important in the elimination of GaHV-1 from the houses. However, continuous production without fallow period is a common practice in farms in the Mantiqueira Highlands region. GaHV-1 can survive in drinker biofilms for several days, and in tracheal mucus on a wooden surface for up to three months at $20^{\circ} \mathrm{C}-23^{\circ} \mathrm{C}$, if protected from light (Ou et al. 2011).

The farms in the quarantined region carried out manure treatment by composting, which prevents the spread of pathogens. The heating of the manure from sheds at $38^{\circ} \mathrm{C}$ for 24 hours, combined with disinfectant use or fermentation (composting) at $38^{\circ} \mathrm{C}$ for at least 5 days, contributes to GaHV-1 elimination from houses (Ou et al. 2011). However, as some farms transport manure for composting onto other properties, the trucks used for this transport represent a potential risk for ILT virus spread and should be continuously monitored.

During the study period, the actions of the SVO were fundamental to preventing the spread the of the virus to other regions. Farms outside the quarantined area were kept infection free for 8 years (2010-2018). The following practices were efficient epidemiological surveillance actions: the vaccination of chickens quarantined in the farms, manure treatment, controlled transportation of manure, chickens, and other waste from farms, sanitary education programmes, restrictive measures to improve biosecurity, and monitoring of ILT cases. This demonstrates that animal health defence helps to prevent the spread of GaHV-1 to other areas and thus avoids greater economic, health, and social damage.

The OIE considers that official veterinary services represent a global public heritage, requiring infrastructure and investments from the signatory countries of the World Trade Organisation (WTO) and the World Organisation for Animal Health, formerly the Office International des Epizooties (OIE 2019). The quality of the Brazilian SVO, specifically the IMA, must be assured, because it is of strategic importance that the country complies with the recommendations of the OIE. The state of Minas Gerais represents the second-largest producer and the largest exporter of table eggs in Brazil. In 2014, the OIE evaluated the Brazilian SVO using the Performance Vision Strategy (PVS) methodology, reporting that its technical capacity was of good quality (CVP 2014).

\section{CONCLUSIONS}

The infectious laryngotracheitis (ILT) virus remains present in Brazil. In the State of Minas Gerais, it is restricted to the Mantiqueira Highlands region, confirming that the control measures taken by the "Serviço Veterinário Oficial" (SVO) of the "Instituto Mineiro Agropecuário" (IMA) and "Ministério da Agricultura, Pecuária e Abastecimento" (MAPA) were effective. Vigilance must be maintained in the region to mitigate the risk of new outbreaks and the spread of GaHV-1 to other regions of the state and country.

The biosecurity improvement program on farms in the region conferred significant improvements from 2010 to 2018, but it should adopt additional measures in future.

The methodology used to assess biosecurity on the farms was useful in this assessment, and new studies should validate it further.

Funding source.- This research was financially supported by the "Fundação de Amparo à Pesquisa do Estado de Minas Gerais" (FAPEMIG), project grant number APQ-01571-14. Two authors received a research fellowship from "Coordenação de aperfeiçoamento de Pessoal de Nível Superior" (CAPES), Brazil - Finance Code 001, and the "Conselho Nacional de Desenvolvimento Científico e Tecnológico” (CNPq), Brazil.

Acknowledgments.- We are thankful to the veterinarians of "Instituto Mineiro de Agropecuária" (IMA) (Luiz Antônio Torino, Simone Guimarães Palma, Graciene Maciel, Laura Freitas Canêdo, and Emilson Coutinho) and of the "Ministério da Agricultura Pecuária e Abastecimento" (Denise Viégas, Bruno R. Pessamilio, Dilmara Reischak, and Ivy Campos), for collaboration in sample collection.

Conflict of interest statement.- The authors declared no potential conflicts of interest with respect to the research, authorship, and/or publication of this article.

\section{REFERENCES}

Bagust T.J. 1986. Laryngotracheitis (Gallid-1) herpesvirus infection in the chicken. Latency establishment by wild and vaccine strains of ILT virus. Avian Pathol. 15(3):581-595. <https://dx.doi.org/10.1080/03079458608436317> $<$ PMid:18766556>

Callison S.A., Riblet S.M., Oldoni I., Sun S., Zavala G., Williams S., Resurreccion R.S., Spackman E. \& García M. 2007. Development and validation of a realtime Taqman ${ }^{\circledR} \mathrm{PCR}$ assay for the detection and quantitation of infectious laryngotracheitis virus in poultry. J. Virol. Methods 139(1):31-38. <https:// dx.doi.org/10.1016/j.jviromet.2006.09.001><PMid:17030068>

Chin R.P., García M., Corsiglia C., Riblet S., Crespo R., Shivaprasad H., RodriguezAvila A., Woolcock P.R. \& França M. 2009. Intervention strategies for laryngotracheitis: impact of extended downtime and enhanced biosecurity auditing. Avian Dis. 53(4):574-577. <https://dx.doi.org/10.1637/8873041309-Reg.1 ><PMid:20095159>

Coppo M.J.C., Noormohammadi A.H., Browning G.F. \& Devlin J.M. 2013. Challenges and recent advancements in infectious laryngotracheitis virus vaccines. Avian Pathol. 42(3):195-205. <https://dx.doi.org/10.1080/030 79457.2013.800634><PMid:23718807>

Couto R. de M., Braga J.F.V., Gomes S.M., Resende M., Martins N.R. \& Ecco R. 2016 Natural concurrent infections associated with infectious laryngotracheitis in layer chickens. J. Appl. Poultry Res. 25(1):113-128. <https://dx.doi. org/10.3382/japr/pfv075>

Couto R. de M., Preis I.S., Braga J.F.V., Brasil B.S.A.F., Drummond M.G., Martins N.R. da S. \& Ecco R. 2015. Molecular characterization of infectious laryngotracheitis virus in naturally infected egg layer chickens in a multi-age 
flock in Brazil. Arch. Virol. J. 160(1):241-252. <https://dx.doi.org/10.1007/ s00705-014-2273-2> <PMid:25385176>

Crawshaw G.J. \& Boycott B.R. 1982. Infectious laryngotracheitis in peafowl and pheasants. Avian Dis. 26(2):397-401. <PMid:6285883>

CVP 2014. Comité Veterinário Permanente Del Cono Sur. Available at <http://www.cvpconosur.org/wp-content/uploads/2015/04/InformeBrasilfebrero14.pdf> Accessed on Jan. 1, 2020.

Dufour-Zavala A.L. 2008. Epizootiology of infectious laryngotracheitis and presentation of an industry control program. Avian Dis. 52(1):1-7. <https://dx.doi.org/10.1637/8018-051007-Review><PMid:18459288>

Fletcher O.J. \& Abdul-Aziz T. 2016. Respiratory system, p.195-269. In: AbdulAziz T., Fletcher O.J., Barnes J.H., Shivaprasad H.L. \& Swayne D.E. (Eds), Avian Histopathology. 4th ed. American Association of Avian Pathologists, Jacksonville.

García M. 2017. Current and future vaccines and vaccination strategies against infectious laryngotracheitis (ILT) respiratory disease of poultry. Vet. Microbiol. 206:157-162. <https://dx.doi.org/10.1016/j.vetmic.2016.12.023> <PMid:28057380>

Guy J.S., Barnes H.J. \& Smith L.G. 1991. Increased virulence of modified-live infectious laryngotracheitis vaccine virus following bird-to-bird passage. Avian Dis. 35(2):348-355. <PMid:1649591>

Guy J.S., García M. \& Spatz S. 2013. Infectious laryngotracheitis, p.161-180. In: Saif Y.M., Fadly A.M., Glisson J.R., McDougald L.R., Nolan L.K. \& Swayne D.E., (Eds), Diseases of Poultry. 13th ed. Iowa State University Press, Ames.

Hayashi S., Odagiri Y., Kotani T. \& Horiuchi T. 1985. Pathological changes of tracheal mucosa in chickens infected with infectious laryngotracheitis virus. Avian Dis. 29(4):943-950. <PMid:3008702>

Hughes C.S., Gaskell R.M., Jones R.C., Bradbury J.M. \& Jordan F.T. 1989. Effects of certain stress factors on the re-excretion of infectious laryngotracheitis virus from latently infected carrier birds. Res. Vet. Sci. 46(2):274-276. <https://dx.doi.org/10.1016/S0034-5288(18)31158-5><PMid:2539638>

Hughes C.S., Williams R.A., Gaskell R.M., Jordan F.T.W., Bradbury J.M., Bennett M. \& Jones R.C. 1991. Latency and reactivation of infectious laryngotracheitis vaccine virus. Arch. Virol.121(1/4):213-218. <https://dx.doi.org/10.1007/ BF01316755> <PMid:1662039>

ICTV 2011. Herpesviridae. ICTV 9th Report, International Committee on Taxonomy of Viruses. Available at <https://talk.ictvonline.org/ictv-reports/ ictv_9th_report/dsdna-viruses-2011/w/dsdna_viruses/91/herpesviridae> Accessed Feb. 16, 2018.

Johnson D.I., Vagnozzi A., Dorea F., Riblet S.M., Mundt A., Zavala G. \& García M. 2010. Protection against infectious laryngotracheitis by in ovo vaccination with commercially available viral vector recombinant vaccines. Avian Dis. 54(4):1251-1259. <https://dx.doi.org/10.1637/9401-052310-Reg.1> <PMid:21313847>

Johnson Y.J., Colby M.M., Tablante N.L., Hegngi F.N., Salem M., Gemadu N. \& Pope C. 2004. Application of commercial and backyard poultry geographic information system databases for the identification of risk factors for clinical infectious laryngotracheitis in a cluster of cases on the Delmarva peninsula. Int. J. Poultry Sci. 3(3):201-205. <https://dx.doi.org/10.3923/ ijps.2004.201.205>

Kingsbury F.W. \& Jungherr E.L. 1958. Indirect transmission of infectious laryngotracheitis in chickens. Avian Dis. 2(1):54-63. <https://dx.doi. org/10.2307/1587512>

OIE 2018. Avian Infectious Laryngotracheitis. Terrestrial Manual 3.3.3, Office International des Epizooties, Paris, p.810-820.

OIE 2019. Office International des Epizooties, Paris. Available at <https:// www.oie.int/en/animal-health-in-the-world/wahis-portal-animal-healthdata,2019> Accessed on Jan. 1, 2020.

Ou S., Giambrone J.J. \& Macklin K.S. 2011. Infectious laryngotracheitis vaccine virus detection in water lines and effectiveness of sanitizers for inactivating the virus. J. Appl. Poultry Res. 20(2):223-230. <https://dx.doi. org/10.3382/japr.2010-00300>

Pitesky M., Chin R.P., Carnaccini S., Sentíes-Cué C.G., Charlton B., Woolcock P.R. \& Shivaprasad H.L. 2014. Spatial and temporal epidemiology of infectious laryngotracheitis in Central California: 2000-2012. Avian Dis. 58(4):558-565. <https://dx.doi.org/10.1637/10727-112113-Reg.1><PMid:25619000>

Portz C., Beltrão N., Furian T.Q., Júnior A.B., Macagnan M., Griebeler J., Rosa C.A.V.L., Colodel E.M., Driemeier D., Back A., Schatzmayr O.M.B. \& Canal C.W. 2008. Natural infection of turkeys by infectious laryngotracheitis virus. Vet. Microbiol. 131(1/2):57-64. <https://dx.doi.org/10.1016/j. vetmic.2008.02.029><PMid:18436397>

Volkova V., Thornton D., Hubbard S.A., Magee D., Cummings T., Luna L., Watson J. \& Wills R. 2012. Factors associated with introduction of infectious laryngotracheitis virus on broiler farms during a localized outbreak. Avian Dis. 56(3):521-528. <https://dx.doi.org/10.1637/10046-122111-Reg.1> <PMid:23050469>

Williams R.A., Bennett M., Bradbury J.M., Gaskell R.M., Jones R.C. \& Jordan F.T.W. 1992. Demonstration of sites of latency of infectious laryngotracheitis virus using the polymerase chain reaction. J. General Virol. 73(Pt 9):2415-2420. <https://dx.doi.org/10.1099/0022-1317-73-9-2415><PMid:1328497>

Yamada S., Matsuo K., Fukuda T. \& Uchinuno Y. 1980. Susceptibility of ducks to the virus of infectious laryngotracheitis. Avian Dis. 24(4):930-938. <PMid:6268043> 